\title{
PERTUMBUHAN, KEMATIAN DAN TINGKAT EKSPLOITASI KERANG POKEA (BATISSA VIOLACEA VAR. CELEBENSIS, VON MARTENS 1897) PADA SEGMEN MUARA SUNGAI LASOLO SULAWESI TENGGARA
}

\begin{abstract}
The Growth, Mortality and Exploitation Level of Pokea (Batissa violacea var. celebensis, von Martens 1897) at Estuary Segment in Lasolo River Southeast Sulawesi
\end{abstract}

Oleh:

\author{
Bahtiar $^{1 *}$, La Anadi ${ }^{1}$, Wa Nurgayah ${ }^{1}$, Emiyarti $^{1}$, Harmin Hari $^{1}$ \\ ${ }^{1}$ Fakultas Perikanan dan Ilmu Kelautan, Universitas Halu Oleo \\ *Korespondensi: tiar_77unhalu@yahoo.com
}

Diterima: 29 Maret 2016; Disetujui: 14 September 2016

\begin{abstract}
Pokeas (Batissa violacea var. celebensis, von Martens 1897) are economic Sulawesi's clam which production has continued to decline in line with the increase in fishing activities. This study aimed to determine the parameters of growth, mortality and exploitation level of pokea at estuary segment in Lasolo River, Southeast Sulawesi. The results of this study are expected to be a reference in the management of pokea resources in Southeast Sulawesi. Data segregation for age group, growth, mortality (natural, catches and total) and the degree of exploitation were analized by Bhattacharya method, inverse model von Bertalanffy, length converted catch curve and empirical Pauly, that accommodated in FiSAT II version 1.1.3. Results showed that male and female pokea were distributed as juvenile, adult to broodstock, dominated by adult. The growth pattern $(L t)$ of male and female, was $=6.46-(6.46-0.025) \mathrm{e}^{-2.8 t}$ and $L t=7.79-(7.79-0.025) \mathrm{e}^{-0.5 t}$, respectively. Natural mortality $(M)$, fishing mortality $(F)$ and total mortality $(Z)$ in males were found higher than females. In general, the utilization level of pokea in the Lasolo river has experienced over exploitation.
\end{abstract}

Keywords: clam, Lasolo River, management resources, pokea, Southeast Sulawesi

\section{ABSTRAK}

Kerang pokea (Batissa violacea var. celebensis, von Martens 1897) merupakan kerang ekonomis dari Sulawesi yang produksinya terus mengalami penurunan sejalan dengan peningkatan aktivitas pengambilannya di alam. Penelitian ini bertujuan untuk mengetahui parameter pertumbuhan, kematian dan tingkat eksploitasi kerang pokea di segmen muara Sungai Lasolo Sulawesi Tenggara. Hasil penelitian ini diharapkan dapat dijadikan rujukan dalam pengelolaan sumberdaya kerang pokea di Sulawesi Tenggara. Data pemisahan kelompok umur, pertumbuhan, kematian (alami, tangkapan dan total) dan tingkat eksploitasi masing-masing menggunakan metode Bhattacharya, model inverse von Bertalanffy, hasil tangkapan yang dikonversi dari data lebar cangkang dan empiris Pauly yang terakomodasi dalam program FiSAT II versi 1.1.3. Hasil penelitian menunjukkan bahwa pokea jantan dan betina tersebar dari ukuran anak, dewasa dan tua yang didominasi pada ukuran dewasa. Pola pertumbuhan jantan dan betina masing-masing yaitu: $\mathrm{Lt}=6,46-(6,46-0,025) \mathrm{e}^{-2.8 t}$ dan $\mathrm{Lt}=7,79-(7,79-0,025) \mathrm{e}^{-0.5 t}$. Kematian pokea tertinggi secara alami $(\mathrm{M})$, penangkapan $(\mathrm{F})$ dan total $(\mathrm{Z})$ pada jantan ditemukan lebih tinggi 
dibandingkan kematian pada pokea betina. Secara umum, tingkat pemanfaatan kerang pokea di Sungai Lasolo telah mengalami lebih tangkap.

Kata kunci: kerang, Sungai Lasolo, manajemen sumberdaya, pokea, Sulawesi Tenggara

\section{PENDAHULUAN}

Jazirah Sulawesi Tenggara merupakan salah satu daerah yang dilalui oleh garis Wallacea yang mempunyai keunikan ekosistem dan biotanya. Salah satu biota yang hidup dan ditemukan di hampir seluruh ekosistem muara sungai di daerah ini adalah "kerang pokea" (Bahtiar et al. 2012a). Pokea merupakan bivalvia yang hidup di beberapa sungai di Sulawesi Tenggara yang mempunyai kekhasan diban-dingkan dengan spesies sejenis dari daerah lain (Muzuni et al. 2014). Kekhasan pokea ini dapat terlihat dari kondisi morfologi dan ekolo-gis perairan yang ditempatinya. Bila dibanding-kan dengan genus yang sama, kerang pokea mempunyai bentuk yang lebih lancip dan hidup pada salinitas sangat rendah (Bahtiar 2012). Kerang pokea merupakan nama lokal bivalvia air tawar Sulawesi Tenggara yang berasal dari spesies Batissa violaceavar celebensis (Kus-noto 1953).

Secara geografi, genus Batissa mempunyai penyebaran yang cukup luas, meliputi bagian barat pasifik (Malaysia, Filipina, Papua Nugini, Australia barat daya) sampai Pasifik Selatan (Fiji) (Dudgeon dan Morton 1989). Menurut Sastrapradja (1977) bahwa B. violacea, Lamarck tersebar di Asia Tenggara dan Australia Utara. Di Indonesia, bivalvia ini tersebar pada beberapa pulau besar yaitu: Sumatera (Putri 2005), Jawa (Sastrapradja 1977), Papua Barat (Djajasasmita 1977) dan Sulawesi (Kusnoto 1953). Di Sulawesi Tenggara, jenis ini ditemukan tersebar merata di sepanjang Jazirah Tenggara terutama pada beberapa sungai besar seperti Sungai Pohara, Sungai Lasolo, Sungai Laeya dan Sungai Roraya (Bahtiar et al. 2012a).

Kerang pokea di Sulawesi Tenggara merupakan sumberdaya yang bernilai ekonomis penting. Kerang ini tercatat mempunyai produksi yang sangat besar. Berdasarkan hasil penelitian Bahtiar (2012) menunjukkan bahwa produksi pokea hanya pada satu sungai (Sungai Pohara) yang didaratkan di tempat pendaratan pokea (TPP) pada tahun 2012 sebesar 155 ton. Kondisi ini merupakan potensi yang dapat dikembangkan sebagai kekuatan pangan lokal. Sejalan dengan hal tersebut di atas, pengambilan pokea di alam yang telah menjadi mata pencaharian penduduk di sekitar sungai tersebut memberikan dampak pada penurunan jumlah pokea ini dari tahun ke tahun. Hal ini ditandai dengan hasil tangkapan yang terus menurun dan ukuran populasi yang cenderung semakin kecil. Berdasarkan hasil penelitian Bahtiar et al. (2012b) bahwa pokea hanya dapat dihasilkan $\pm 10-15 \mathrm{~kg} / \mathrm{jam}$ dari yang sebelumnya dapat dihasilkan $\pm 25-30 \mathrm{~kg} / \mathrm{jam}$. Demikian halnya ukuran kerang yang ditemukan di pasar yang didominasi ukuran kecil yaitu $3 \mathrm{~cm}$ yang sebelumnya berada pada ukuran 5-6 cm (Bahtiar et al. 2008). Di sisi lain, pertumbuhan, kematian dan tingkat eksploitasi kerang pokea di Sungai Lasolo belum diketahui secara pasti sedangkan hal tersebut sangat penting untuk mengetahui dinamika populasi bagi tujuan pengelolaan sumberdaya kerang pokea di alam. Oleh karena itu, perlu dilakukan penelitian tentang pertumbuhan, kematian dan tingkat eksploitasi kerang pokea di Sungai Lasolo Sulawesi Tenggara.

Penelitian ini bertujuan untuk mengetahui parameter pertumbuhan, kematian dan tingkat eskploitasi kerang pokea di segmen muara Sungai Lasolo Sulawesi Tenggara. Hasil penelitian ini diharapkan dapat dijadikan rujukan dalam pengelolaan sumberdaya kerang pokea di Sulawesi Tenggara.

\section{METODE}

Penelitian ini dilaksanakan selama satu tahun dimulai dari bulan Januari sampai Desember 2014. Pengukuran sampel kerang pokea dilakukan di Laboratorium Fakultas Perikanan Universitas Halu Oleo. Pengambilan sampel dilakukan di segmen muara Sungai Lasolo Sulawesi Tenggara (Gambar 1).

Sampel pokea diambil menggunakan alat tangkap tangge (alat tangkap tradisional) di 5 titik pengambilan dari $\mathrm{S}=03^{\circ} 30^{\prime} 20.3^{\prime \prime} \mathrm{E}=122^{\circ}$ 09'05.9" sampai $S=03^{\circ} 31^{\prime} 55,1^{\prime \prime} \quad E=122^{\circ} 13^{\prime}$ 14,6". Jumlah tarikan pengambilan sebanyak 10 kali dalam setiap titik. Selanjutnya sampel dikompositkan karena kerang pokea yang terdapat pada seluruh titik pada seluruh segmen muara Sungai Lasolo berasal dari satu stok sehingga mempunyai parameter-parameter populasi yang sama (Bahtiar, 2012). Sampel kualitas air (suhu perairan) diambil bersamaan dengan pengambilan kerang pokea. Lebar cangkang kerang pokea diukur menggunakan jangka sorong ketelitian $0,05 \mathrm{~cm}$. Jenis kelamin diketahui dengan mengamati warna gonad 


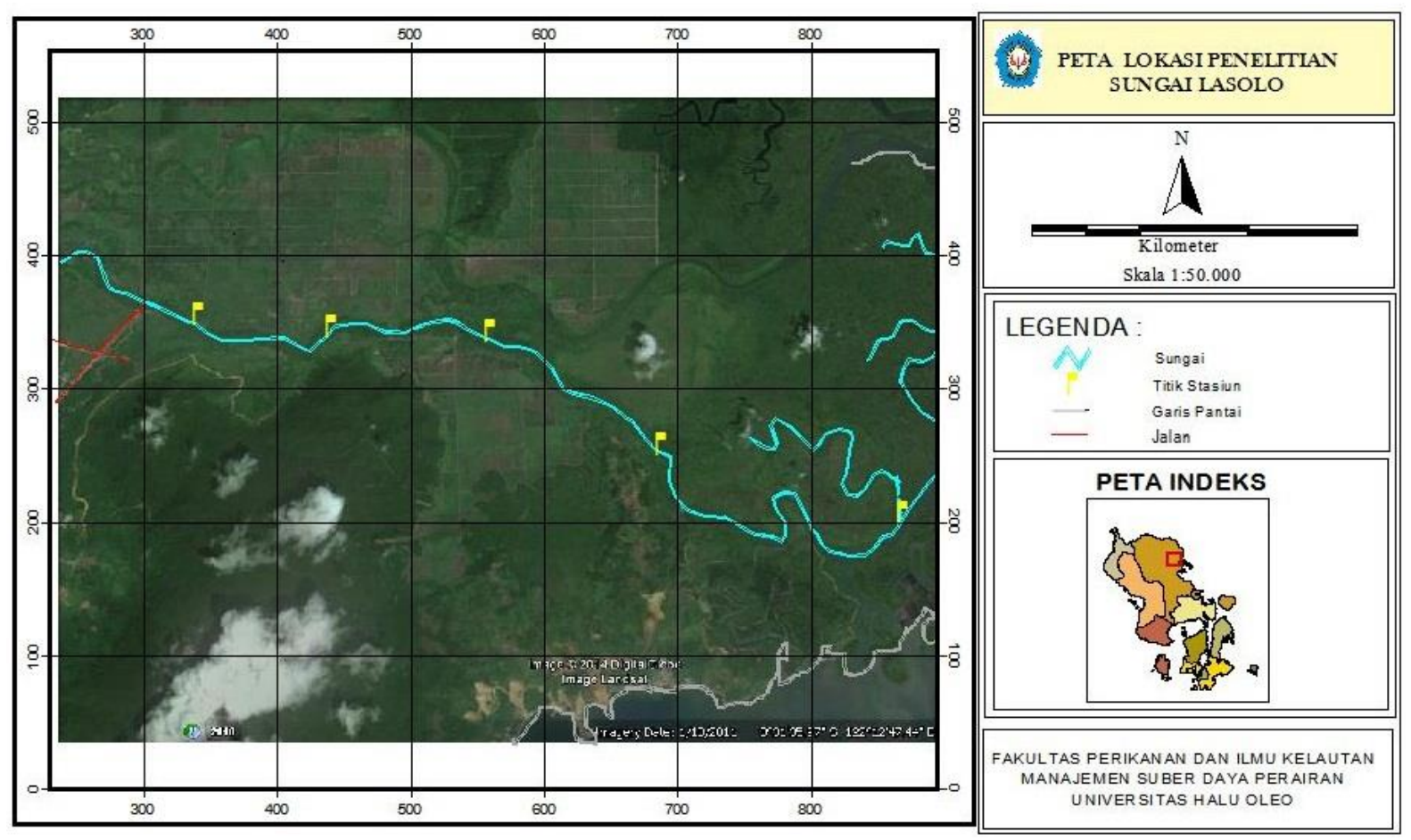

Gambar 1. Peta Lokasi Penelitian di Sungai Lasolo Sulawesi Tenggara

kerang. Jantan mempunyai warna putih dan betina berwarna coklat (Bahtiar 2012).

Data yang dikumpulkan selanjutnya diolah dengan menggunakan paket program FiSAT II versi 1.1.3 (FAO-ICLARM Fish Stock Asessement Tools) yang terdiri atas: 1) kelompok ukuran menggunakan program normsep, 2) pertumbuhan menggunakan program ELEFAN dan pendugaan laju mortalitas dan tingkat eksploitasi menggunakan kurva hasil tangkapan yang dikonversikan ke lebar cangkang (widthconverted catch curve) (Sparre dan Venema 1999).

Selanjutnya pendekatan analisis data dilakukan terhadap: kelompok umur, pertumbuhan, mortalitas dan status eksploitasi, sebagai berikut:

\section{Kelompok umur}

Analisis pemisahan kelompok-kelompok umur pokea didasarkan pada ukuran lebar cangkang yang menggunakan metode Bhattacharya. Metode Bhattacharya merupakan salah satu grafis untuk memisahkan data sebaran frekuensi lebar cangkang ke dalam beberapa distribusi normal (Gayanilo dan Pauly 2002).

\section{Pertumbuhan}

Pendugaan parameter pertumbuhan menggunakan inverse von Bertalanffy seperti yang disarankan oleh (Bretos 1980; Hughes dan Roberts 1980; Narasimham 1981; dan Anthony et al. 2001) yaitu:

$$
\begin{aligned}
& L t=L_{\infty}-\left(L_{\infty}-L O\right) e^{-K t} \\
& L_{t} \quad=\text { panjang kerang pada saat } \mathrm{t}(\mathrm{mm}) \\
& L_{\infty} \quad=\text { panjang asimtot } / \text { maksimum kerang } \\
& (\mathrm{mm}) \\
& K=\text { koefisien pertumbuhan (per tahun) } \\
& L_{0} \quad=\text { ukuran kerang pada saat larva atau } \\
& \text { glochidia (Anthony et al. 2001). } \\
& =\text { umur kerang pada saat } L_{t} \text { (tahun) }
\end{aligned}
$$

\section{Mortalitas}

Pendugaan terhadap koefisien kematian alami (M) digunakan persamaan empiris Pauly yaitu :

$$
\begin{aligned}
\log (M)= & -0,0066-0,279 \log L_{\infty}+0,6543 \log K \\
& +0,463 \log T
\end{aligned}
$$

Pendugaan laju mortalitas total (Z) dihitung dengan menggunakan persamaan yaitu:

$$
L n \frac{C(L 1, L 2)}{\Delta t(L 1, L 2)}=C-Z * t \frac{(L 1+L 2)}{2}
$$

keterangan:

$$
\begin{array}{ll}
C & =\text { hasil tangkapan kumulatif } \\
L & =\text { panjang }(\mathrm{cm}) \\
Z & =\text { koefisien kematian total } \\
L 1, L 2 & =\text { dari panjang } L 1 \text { ke panjang } L 2 \\
t & =\text { waktu } \\
\Delta t & =\text { waktu yang dibutuhkan }
\end{array}
$$

Persamaan di atas dapat disederhanakan menjadi: 


\author{
$\ln \left(N_{i} / \Delta t_{i}\right)=a+b \cdot t_{i}$ \\ keterangan: \\ $N_{i} \quad=$ Jumlah pokea pada kelas lebar ke-i \\ $\Delta t_{i} \quad=$ waktu yang dibutuhkan pokea \\ selama kelas lebar ke-i \\ $Z \quad=\quad$ kematian total pokea $\left(\mathrm{yr}^{-1}\right)$ \\ $a$ dan $b=$ koefisien regresi $(\mathrm{b}=-\mathrm{Z})$ \\ $t \quad=$ umur yang dihitung dari $\mathrm{t} 0=0$
}

\section{Status Eksploitasi (E)}

Pendugaan status eksploitasi (tingkat pemanfaatan) stok dapat diduga dengan rumus (Sparre dan Venema, 1999):

keterangan:

$$
E=F /(F+M)
$$

$E=$ status eksploitasi

$F=$ koefisien kematian penangkapan

$M=$ koefisien kematian alami

Jika $\mathrm{E}>0,5$ menunjukkan tingkat eksploitasi tinggi (over fishing), $\mathrm{E}=0,5$ menunjukkan pemanfaatan optimal ( $E$ opt), dan $E<0,5$ menunjukkan tingkat eksploitasi rendah (under fishing) (Gulland 1977).

\section{HASIL}

\section{Kelompok Ukuran}

Hasil analisis kelompok umur menunjukkan bahwa kerang pokea di muara Sungai Lasolo terdiri atas 1, 2 atau 3 kelompok ukuran (distribusi normal), dengan kelompok ukuran dominan di setiap bulannya adalah 2 kelompok ukuran. Jantan terdiri atas 1,2 dan 3 kelompok ukuran dan didominasi oleh 2 kelompok ukuran yang terdistribusi dari ukuran 2,23-4,95 cm. Demikian halnya pada betina yang terdiri atas 1,2 dan 3 kelompok ukuran dan didominasi oleh 2 kelompok ukuran yang terdistribusi dari ukuran 2,65-6,15 cm. Secara umum, baik jantan maupun betina menunjukkan adanya kelompok ukuran kecil $(2 \mathrm{~cm})$ dan besar (4-6 $\mathrm{cm})$ di setiap bulannya dan terjadi perubahan/pergeseran kelompok ukuran kerang pokea pada sisi kanan pada beberapa bulan dan diikuti pergeseran kelompok ukuran pada sisi kiri dalam bulan berikutnya (Gambar 2 dan Tabel 1).

\section{Pertumbuhan}

Nilai $L \infty$ pada jantan lebih kecil dibandingkan pada betina, namun koefisien pertumbuhan pada jantan lebih besar dibandingkan betina. Oleh karena itu, jantan lebih cepat mencapai umur dewasa dan tua dibandingkan betina. Jantan membutuhkan 2-3 tahun untuk mencapai $L \infty$ sedangkan $L \infty$ betina dapat dicapai pada umur 9-10 tahun. Persamaan pertumbuhan jantan dan betina masing-masing : $\mathrm{Lt}=6,46$ $(6,46-0,025) \mathrm{e}^{-2,8 t}$ dan Lt $=7,79-(7,79-0,025) \mathrm{e}$ 0,5 . Pertumbuhan jantan dan betina sangat cepat terjadi pada umur masing-masing $(0,1-$ 0,8 tahun dan 0,10-2,5 tahun). Pertumbuhan pokea berjalan semakin lambat seiring dengan pertambahan umur sampai mencapai pertumbuhan maksimun (Gambar 3).

\section{Kematian dan Tingkat Eksploitasi}

Kematian penangkapan (F) pokea jantan lebih tinggi dibandingkan dengan kematian alami (M) dengan nilai masing-masing adalah $10 \mathrm{yr}^{-1}$ dan $5.24 \mathrm{yr}^{-1}$. Hal yang berbeda ditunjukkan pada kematian kerang pokea betina bahwa kematian alami dan kematian penangkapan berada pada nilai yang relatif sama yaitu $1.6 \mathrm{yr}^{-1}$. Kematian alami, kematian penangkapan dan kematian total kerang pokea jantan ditemukan lebih tinggi dibandingkan kematian pada kerang pokea betina. Secara umum, kematian penangkapan jauh lebih tinggi dibandingkan kematian alami dan tingkat pemanfaatan kerang pokea berada pada kondisi over eksploitasi (Gambar 4).

\section{PEMBAHASAN}

Kelompok umur yang ditemukan pada kerang pokea jantan dan betina di Sungai Lasolo terdistribusi dari kelompok anak, dewasa dan tua, karena ukuran dengan nilai tengah 2,23 cm merupakan kelompok umur yang belum matang gonad, dan nilai tengah $6,15 \mathrm{~cm}$ merupakan kelompok umur tua, yang telah mendekati panjang maksimun yang dicapai oleh kerang. Hal ini sesuai dengan penelitian Bahtiar (2012) bahwa kerang matang gonad yang menjadi ukuran kedewasaan kerang jantan dan betina masing-masing dimulai pada ukuran 2,35 dan 2,4 $\mathrm{cm}$. Oleh karena itu, populasi kerang pokea di sungai ini relatif stabil karena: 1 ) adanya keterwakilan dari setiap kelompok umur yang menopang regenerasi, 2) dominannya kelompok umur yang matang gonad $(>3 \mathrm{~cm})$ dan dapat memijah, dan 3) adanya rekrutmen kelompok umur yang muda dalam setiap bulan yang ditandai dengan distribusi umur kerang anakan yang ditemukan di setiap bulan atau adanya pergeseran kelompok ukuran kerang pokea pada sisi kiri. Struktur populasi kerang pokea di Sungai Lasolo relatif sama dengan yang ditemukan di Sungai Pohara yang berada pada kelompok umur anak, dewasa, dan tua dengan kondisi yang stabil (Bahtiar et al. 2008 dan Bahtiar et al. 2014ª, Bahtiar et al. 2015). 
Tabel 1 Kelompok ukuran, nilai tengah dan standar deviasi kerang pokea

\begin{tabular}{|c|c|c|c|}
\hline \multirow{2}{*}{ Bulan } & \multirow{2}{*}{ Kelompok Ukuran } & \multicolumn{2}{|c|}{ Nilai Tengah dan Standar Deviasi (cm) } \\
\hline & & Jantan & Betina \\
\hline \multirow{2}{*}{ Januari } & 1 & $2,33 \pm 0,49$ & $2,65 \pm 0,58$ \\
\hline & 2 & $3,94 \pm 0,63$ & - \\
\hline \multirow{2}{*}{ Februari } & 1 & $2,50 \pm 0,51$ & $3,09 \pm 0,45$ \\
\hline & 2 & - & $4,62 \pm 0,55$ \\
\hline \multirow{2}{*}{ Maret } & 1 & $2,61 \pm 0,49$ & $3,25 \pm 0,44$ \\
\hline & 2 & $4,32 \pm 0,88$ & - \\
\hline \multirow{2}{*}{ April } & 1 & $2,57 \pm 0,52$ & $3,21 \pm 0,43$ \\
\hline & 2 & $3,99 \pm 0,48$ & $4,34 \pm 0,19$ \\
\hline \multirow{2}{*}{ Mei } & 1 & $2,57 \pm 0,48$ & $3,05 \pm 0,52$ \\
\hline & 2 & $4,08 \pm 0,37$ & $4,88 \pm 0,57$ \\
\hline \multirow{2}{*}{ Juni } & 1 & $2,23 \pm 0,66$ & $2,97 \pm 0,51$ \\
\hline & 2 & $4,14 \pm 0,29$ & $4,27 \pm 0,3$ \\
\hline \multirow{2}{*}{ Juli } & 1 & $2,55 \pm 0,43$ & $3,04 \pm 0,46$ \\
\hline & 2 & $3,57 \pm 0,58$ & $4,45 \pm 0,26$ \\
\hline \multirow{3}{*}{ Agustus } & 1 & $2,38 \pm 0,46$ & $2,95 \pm 0,55$ \\
\hline & 2 & $3,54 \pm 0,35$ & $5,13 \pm 0,61$ \\
\hline & 1 & $2,65 \pm 0,46$ & $3,01 \pm 0,44$ \\
\hline \multirow[t]{2}{*}{ September } & 2 & $3,65 \pm 0,22$ & - \\
\hline & 3 & $4,95 \pm 0,30$ & - \\
\hline \multirow[t]{2}{*}{ Oktober } & 1 & $2,66 \pm 0,52$ & $3,22 \pm 0,51$ \\
\hline & 1 & $2,58 \pm 0,58$ & $4,0 \pm 0,50$ \\
\hline \multirow[t]{2}{*}{ November } & 2 & - & $4,1 \pm 0,43$ \\
\hline & 3 & - & $6,15 \pm 1,70$ \\
\hline \multirow{2}{*}{ Desember } & 1 & $2,57 \pm 0,42$ & $2,98 \pm 0,42$ \\
\hline & 2 & $4,38 \pm 0,54$ & $4,62 \pm 0,35$ \\
\hline
\end{tabular}

Keterangan : - adalah tidak ditemukan kelompok ukuran pada bulan tersebut

Tabel 2 Parameter pertumbuhan berbagai jenis kerang pada berbagai perairan

\begin{tabular}{|c|c|c|c|c|c|}
\hline Lokasi & Spesies & Jenis Kelamin & $\begin{array}{c}\mathrm{K} \\
\mathrm{yr}\end{array}$ & $\begin{array}{l}\mathrm{L} \infty \\
(\mathrm{cm})\end{array}$ & Sumber \\
\hline Palawan, Philippines & Polymesoda erosa & gabungan $\widehat{\jmath}+$ & 1,00 & 10,71 & $\begin{array}{l}\text { Dolorosa dan } \\
\text { Galon, } 2014\end{array}$ \\
\hline $\begin{array}{l}\text { Sulawesi Tenggara } \\
\text { Indonesia }\end{array}$ & B. violacea & $\begin{array}{l}\hat{0} \\
0\end{array}$ & $\begin{array}{l}0,71 \\
0,91\end{array}$ & $\begin{array}{l}7,84 \\
8,94\end{array}$ & Bahtiar, 2012 \\
\hline Dumai Riau & P. acutidens & gabungan ${ }^{\dagger} 0+$ & 0,59 & 9,27 & Efriyeldi, 2012 \\
\hline Teluk Ambon, Indonesia & Anodonta edentula & gabungan $\delta^{\top}+q$ & 1,50 & 7,06 & Natan, 2009 \\
\hline Sungai Pohara & B. violacea & $\begin{array}{l}0 \\
0 \\
+\end{array}$ & $\begin{array}{l}0,59 \\
0,96\end{array}$ & $\begin{array}{l}7,16 \\
6,92\end{array}$ & Bahtiar et al. 2015 \\
\hline Colombia & Polymesoda solida & gabungan $\hat{\partial} \propto$ & 0,20 & 4,73 & $\begin{array}{l}\text { Rueda dan Urban, } \\
1998\end{array}$ \\
\hline $\begin{array}{l}\text { Bangladesh } \\
\text { India }\end{array}$ & $\begin{array}{l}\text { Meretrix meretrix } \\
\text { Meretrix casta }\end{array}$ & 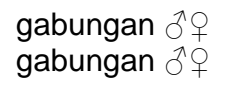 & $\begin{array}{l}0,97 \\
1,81\end{array}$ & $\begin{array}{l}8,14 \\
2,42\end{array}$ & $\begin{array}{l}\text { Amin et al. } 2009 \\
\text { Laxmilatha, } 2013\end{array}$ \\
\hline Pantai Kuba & Donax denticulatus & gabungan $\hat{\jmath}+$ & 1,50 & 2,75 & Ocaña et al. 2013 \\
\hline Pantai Chili & Gari solida & gabungan $\delta \hat{\gamma}$ & 0,30 & 8,96 & $\begin{array}{l}\text { Urban dan } \\
\text { Campos, } 1994\end{array}$ \\
\hline Teluk Persia & Barbatia decussate & gabungan $\widehat{\delta}+q$ & 0,47 & 5,77 & $\begin{array}{l}\text { Zeinalipour et al. } \\
2014\end{array}$ \\
\hline Pantai Mexico & Megapitaria squalid & gabungan $\lesssim \uparrow$ & 0,65 & 8,30 & $\begin{array}{l}\text { Schweers, et al. } \\
2006\end{array}$ \\
\hline Pantai Cidade Brasil & $\begin{array}{l}\text { Anomalocardia } \\
\text { brasiliana }\end{array}$ & gabungan $\widehat{\jmath} \uparrow$ & 0,53 & 4,25 & Corte et al. 2015 \\
\hline Sungai Lasolo & B. violacea & $\begin{array}{c}\hat{0} \\
\text { } 9 \\
\text { gabungan } \widehat{\jmath} 0\end{array}$ & $\begin{array}{l}2,80 \\
0,50 \\
1,80\end{array}$ & $\begin{array}{l}6,46 \\
7,79 \\
8,07\end{array}$ & Penelitian ini \\
\hline
\end{tabular}

Keterangan : $\mathrm{K}=$ koefisien pertumbuhan; $\mathrm{L} \infty=$ panjang infinity 

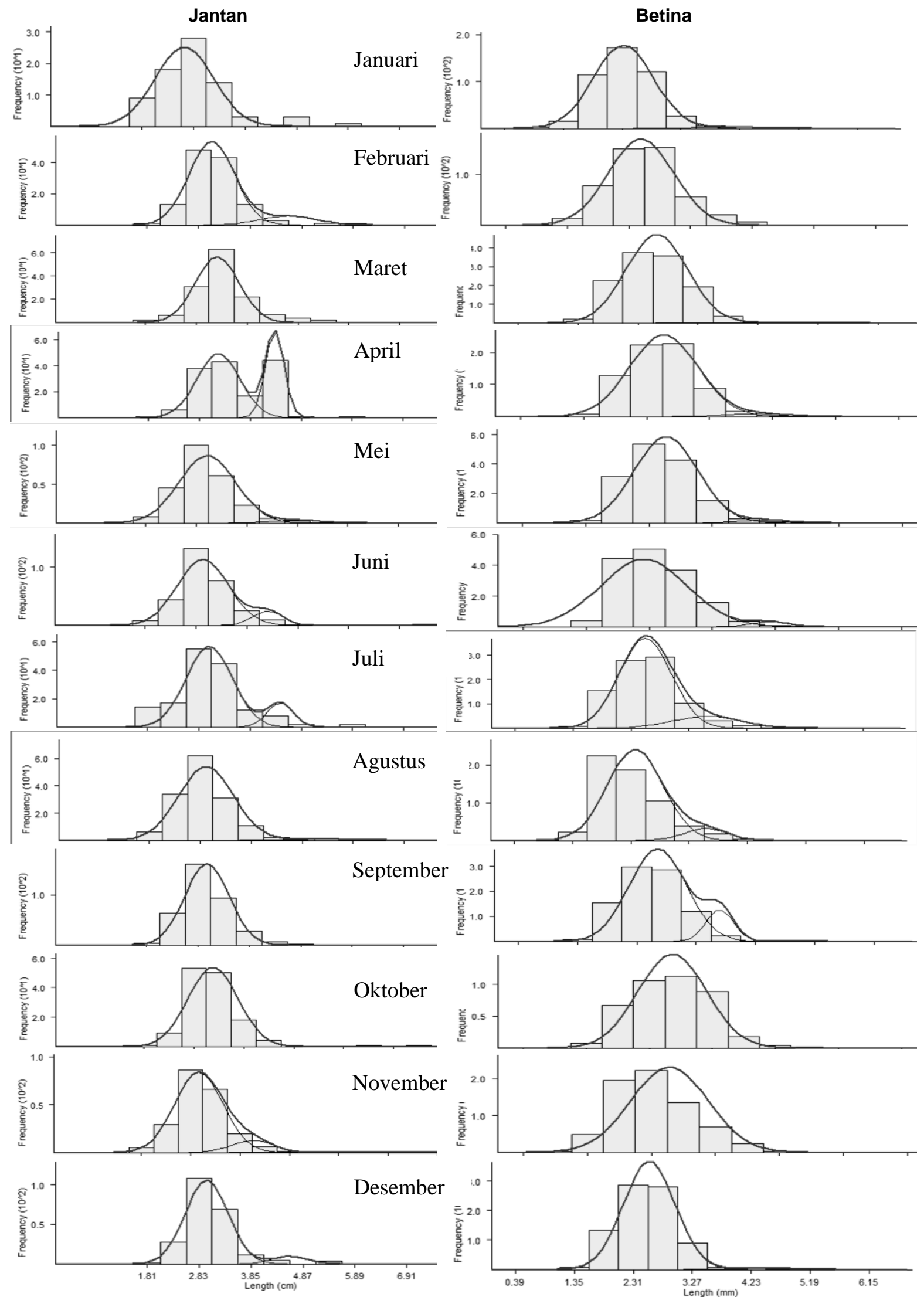

Gambar 2 Kelompok ukuran kerang pokea di Sungai Lasolo Sulawesi Tenggara 


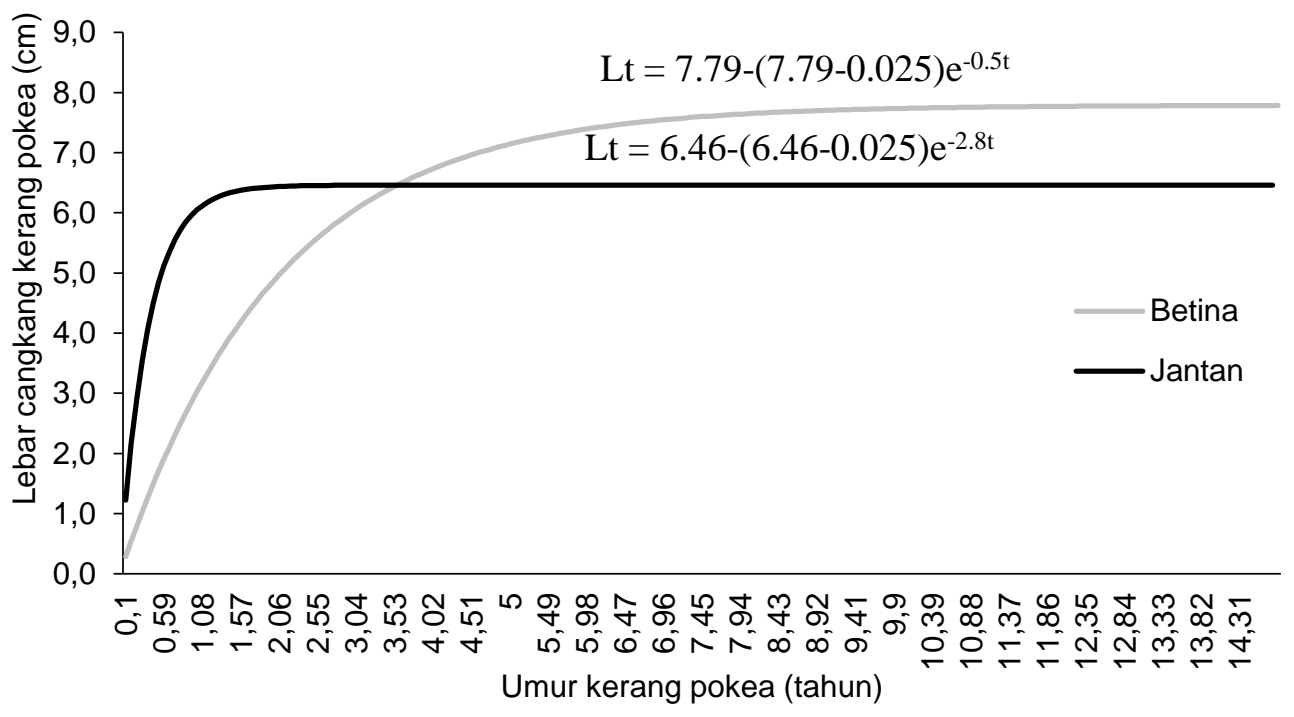

Gambar 3 Pertumbuhan kerang pokea jantan dan betina di Sungai Lasolo Sulawesi Tenggara

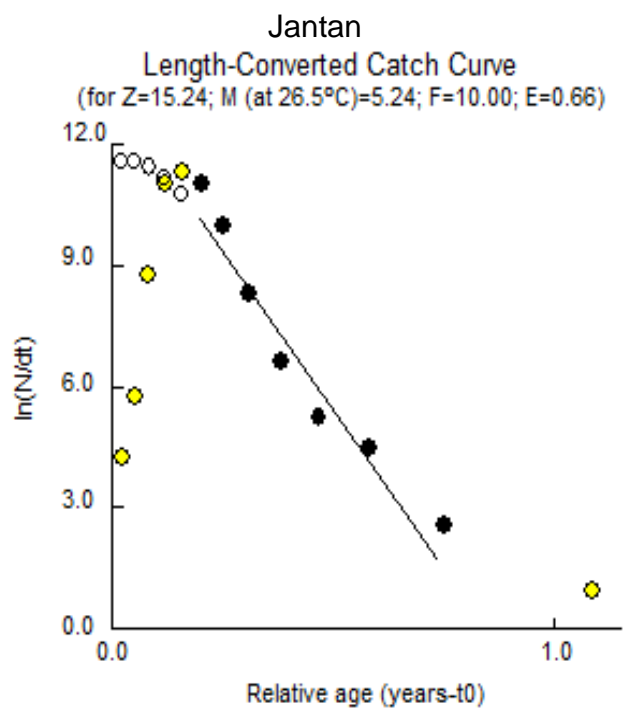

Betina

Length-Converted Catch Curve (for $Z=3.22 ; M\left(\right.$ at $26.5^{\circ} \mathrm{C}$ ) $=1.61 ; F=1.61 ; E=0.50$ )

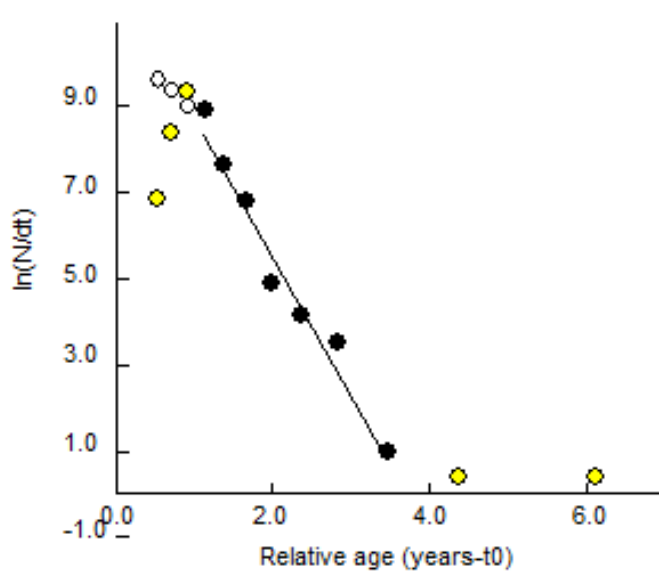

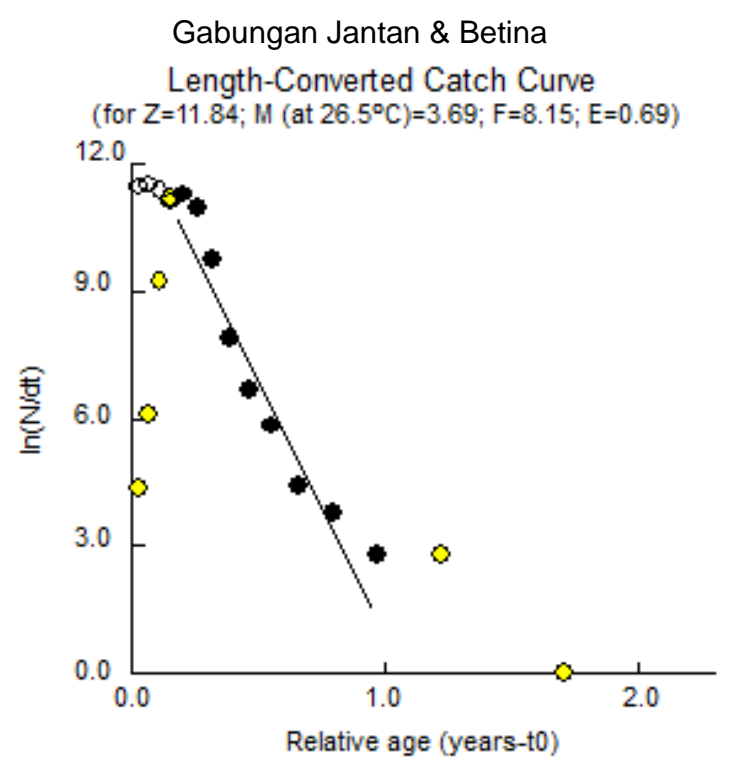

Gambar 4 Pendugaan laju mortalitas total kerang pokea di Sungai Lasolo 
Tabel 3 Perbandingan laju mortalitas kerang di beberapa perairan

\begin{tabular}{|c|c|c|c|c|c|c|c|}
\hline Lokasi & Spesies & $\begin{array}{c}\text { Jenis } \\
\text { kelamin }\end{array}$ & $\begin{array}{c}\mathrm{Z} \\
\mathrm{yr}^{-1}\end{array}$ & $\begin{array}{c}\mathrm{M} \\
\mathrm{yr}^{-1}\end{array}$ & $\begin{array}{c}F \\
y r^{-1}\end{array}$ & E & Sumber \\
\hline Sulawesi Tenggara & B. violacea & 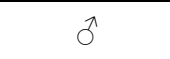 & 5,2 & 2,1 & 3,1 & 0,59 & \multirow{2}{*}{ Bahtiar, 2012} \\
\hline Indonesia & & 우 & 6,46 & 2,39 & 4,07 & 0,63 & \\
\hline Palawan Philippines & $\begin{array}{l}\text { Polymesoda } \\
\text { erosa }\end{array}$ & $\begin{array}{c}\text { gabungan } \\
\text { गै우 }\end{array}$ & 3,74 & 1,41 & 2,33 & 0,62 & $\begin{array}{l}\text { Dolorosa dan } \\
\text { Galon, } 2014\end{array}$ \\
\hline Dumai, Riau & P. acutidens & $\begin{array}{c}\text { gabungan } \\
\delta^{\lambda}+\end{array}$ & 1,87 & 0,39 & 0,94 & 0,50 & Efriyeldi, 2012 \\
\hline Colombia & $\begin{array}{l}\text { Polymesoda } \\
\text { solida }\end{array}$ & $\begin{array}{c}\text { gabungan } \\
\delta^{\Uparrow}+{ }^{\circ}\end{array}$ & 0,95 & 0,76 & 0,19 & 0,2 & $\begin{array}{l}\text { Rueda dan } \\
\text { Urban, } 1998\end{array}$ \\
\hline Bangladesh & Meretrix meretrix & $\begin{array}{c}\text { gabungan } \\
\delta^{\lambda}+\end{array}$ & 2,0 & 1,98 & 0,02 & 0,01 & Amin et al., 2009 \\
\hline India & Meretrix casta & $\begin{array}{c}\text { gabungan } \\
\hat{\jmath} \hat{0}\end{array}$ & 2,96 & 1,98 & 0,98 & 0,33 & Laxmilatha, 2013 \\
\hline $\begin{array}{l}\text { Muara Sungai Volta } \\
\text { Ghana }\end{array}$ & $\begin{array}{l}\text { Galatea } \\
\text { paradoxa }\end{array}$ & $\begin{array}{c}\text { gabungan } \\
\substack{\lambda \\
\delta}\end{array}$ & $\begin{array}{l}0,65- \\
0,82\end{array}$ & $\begin{array}{l}0,35- \\
0,44\end{array}$ & $\begin{array}{l}0,21- \\
0,47\end{array}$ & $\begin{array}{l}0,32- \\
0,57\end{array}$ & $\begin{array}{l}\text { Boateng dan } \\
\text { Wilson, } 2012\end{array}$ \\
\hline \multirow{3}{*}{ Sungai Lasolo } & \multirow{3}{*}{ B. violacea } & $0^{\lambda}$ & 15,24 & 5,24 & 10 & 0,66 & \multirow{3}{*}{ Penelitian ini } \\
\hline & & q & 3,22 & 1,61 & 1,61 & 0,5 & \\
\hline & & $\begin{array}{c}\text { gabungan } \\
\substack{\jmath \\
0}\end{array}$ & 11,84 & 3,69 & 8,15 & 0,69 & \\
\hline
\end{tabular}

Keterangan:

$\mathrm{Z}=$ koefisien kematian

$M=$ koefisien kematian alami

$\mathrm{F}=$ koefisien kematian penangkapan

$E$ = tingkat eksploitasi

Pada kerang yang sama, ukuran pokea jantan ditemukan lebih kecil jika dibandingkan dengan betina seperti pada kerang Batissa violacea di muara sungai lain (Bahtiar 2012 dan Putri 2005). Hal ini diduga sebagai bentuk keseimbangan populasi kerang melalui ukuran kecil jumlah populasi jantan yang lebih besar dan serta siklus hidup hidup yang pendek terhadap jumlah betina yang relatif sedikit dengan ukuran yang besar dengan siklus hidup yang lebih panjang.

Pertumbuhan kerang pokea jantan di Sungai Lasolo lebih cepat dibandingkan kerang lain (Tabel 2). Demikian halnya dengan nilai pertumbuhan dari beberapa jenis bivalvia tawar Unionidae lainnya yang lebih rendah dibandingkan kerang pokea yang ditunjukkan dengan nilai $L \infty$ dan $K$ dari beberapa jenis bivalvia seperti Elliptio complanata dengan nilai masingmasing sebesar 7,40 dan 0,176; Lampsilis siliquoidea sebesar 13,0 dan 0,05 ; serta Pyganodon grandis sebesar 11,20 dan 0,032 (Anthony et al. 2001). Namun hal berbeda ditunjukkan pada pertumbuhan betina yang sangat lambat dibandingkan pokea di Sungai Pohara (Tabel 2). Secara umum, kerang pokea (gabungan jantan dan betina) di Sungai Lasolo mempunyai pertumbuhan dan produktivitas sangat tinggi. Hal ini disebabkan beberapa hal yaitu : 1) habitat pokea yang berada di muara sungai yang menjadi tempat akumulasi sumber makanan dari seluruh bagian sungai, 2) kemampuan pokea mengambil makanan dalam jumlah yang tinggi dalam berbagai bentuk yaitu plankton dan detritus dan 3) mekanisme makan yang tidak hanya sebagai hewan yang menyaring dengan insang (filter feeder) namun juga dilakukan dengan menggunakan kaki (pedal feeder) yang menyapu makanan yang terdapat pada lantai dasar perairan (Bahtiar et al. 2014b). Hal ini diperkuat dengan pernyataan Heilmayer et al. (2004); Paterson et al. (2003) dan Riascos et al. (2007) bahwa perbedaan kecepatan pertumbuhan populasi kerang sangat dipengaruhi oleh ketersediaan makanan di perairan.

Kematian kerang pokea jantan yang lebih tinggi merupakan implikasi dari pertumbuhan populasi yang lebih cepat. Secara umum organisme yang mempunyai pertumbuhan cepat diikuti dengan kematian yang tinggi baik secara alami maupun penangkapan. Kematian alami kerang pokea di alam lebih banyak terjadi pada fase-fase awal daur hidupnya. Walaupun demikian, kematian alami juga dapat terjadi pada kelompok umur anak, dewasa dan tua. Hal ini disebabkan oleh rendahnya kualitas lingkungan habitat kerang pokea hidup diantaranya adalah Total Padatan Tersuspensi (TSS) yang tinggi. Beberapa penelitian pada daerah yang menga- 
lami tekanan ekologis karena tingginya padatan tersuspensi seperti kematian alami dan massal pada kerang pokea yang ditemukan di Sungai Pohara saat penambangan pasir (Bahtiar et al. 2012a). Secara umum, kerang merupakan hewan yang relatif lebih adaptif dan bertahan hidup pada kondisi lingkungan perairan yang tidak mendukung, namun kondisi kualitas lingkungan yang buruk dan massif menyebabkan hewan ini mengalami gangguan fisiologis terutama mekanisme makan dan respirasi yang bersatu sehingga pada kondisi total padatan tersuspensi yang tinggi dan berlangsung dalam waktu panjang yang menyebabkan hewan ini tercekik dan mati (Bahtiar 2012).

Kematian kerang pokea karena penangkapan dapat terjadi dalam beberapa bentuk. Nelayan kerang pokea di Sungai Lasolo mengambil kerang pokea sudah berlangsung sangat lama karena hewan ini sebelum diketahui nilai ekonomisnya dan diperdagangkan, pengambilannya hanya untuk dijadikan sebagai lauk sehari-hari. Pengambilan kerang ini dilakukan dengan cara menyelam dan menggunakan alat paniki (alat serok tradisional). Penurunan jumlah kelompok umur tertentu disebabkan oleh pengambilan kerang yang mengambil ukuran tertentu (dewasa dan tua) sehingga kerang pokea didominasi oleh kelompok umur anakan. Secara umum, kematian penangkapan jauh lebih tinggi dibandingkan kematian alami. Kondisi Sungai Lasolo yang relatif lebih produktif dan jauh dari aktivitas dan dampak pertambangan memberikan kesempatan hidup dan kemampuan regenerasi yang lebih tinggi.

Aktivitas penangkapan kerang pokea di Sungai Lasolo sangat tinggi dibanding daerah lain yang mengusahakan kerang sebagai hewan yang diperdagangkan (bernilai ekonomis penting) dan dieksploitasi di alam sehingga ditemukan pemanfaatan kerang pokea di Sungai Lasolo telah mengalami lebih tangkap (over exploited) (Tabel 3). Kondisi ini menyebabkan kerang ini mengalami tekanan ekologis karena penangkapan. Hal ini dapat diketahui melalui strategi reproduksi ( $r$ strategy) dalam mempertahankan regenerasinya di alam. Kerang pokea jantan dan betina di Sungai Pohara yang mempunyai kemampuan reproduksi yang tinggi yang terjadi pada ukuran sangat kecil yaitu 1,95 $\mathrm{cm}$ dan 2,15 cm (Bahtiar et al. 2015). Perbedaan laju kematian kerang juga dipengaruhi oleh faktor lain seperti kondisi lintang. Kerang yang hidup di perairan tropis cenderung mempunyai kematian yang lebih tinggi di banding kerang pada iklim subtropis. Beberapa jenis kerang subtropis menunjukkan kematian yang rendah seperti Protothaca thaca: $0.47 \mathrm{yr}^{-1}$ (Urban dan Campos 1994), 0,27 $\mathrm{yr}^{-1}$ untuk Callista chione
(Metaxatos 2004), dan Eurhomalea exalbida dengan nilai $0.14 \mathrm{yr}^{-1}$ (Lomovasky et al. 2002).

\section{KESIMPULAN}

Pertumbuhan kerang pokea di Sungai Lasolo sangat cepat yang mengikuti pola $\mathrm{Lt}=$ $6,46-(6,46-0,025) \mathrm{e}^{-2,8 \mathrm{t}}$ dan Lt $=7,79-(7,79$ $0,025) \mathrm{e}^{-0,5 t}$. Oleh karena itu, kualitas lingkungan dan habitat hidup kerang pokea di Sungai Lasolo perlu dijaga dan dipertahankan. Struktur populasi kerang pokea di Sungai Lasolo relatif stabil. Dengan demikian, kebugaran dan keberlanjutan populasi kerang pokea di alam dapat dipertahankan. Kematian penangkapan kerang pokea sangat tinggi yang berimplikasi pada tingkat pemanfaatan yang over eksploitasi. Bila kematian ini tetap berlanjut akan berdampak pada struktur populasi yang tidak stabil dan pada akhirnya menyebabkan hilangnya kerang pokea di Sungai Lasolo.

\section{SARAN}

Pemanfaatan kerang pokea yang telah mengalami lebih tangkapakan berdampak pada penurunan hasil tangkapan kerang pokea di alam pada masa yang akan datang. Oleh karena itu, perlu adanya penelitian lebih lanjut untuk mendapatkan suatu bentuk pengelolaaan yang moderat melalui ukuran pokea yang boleh ditangkap dikombinasikan dengan biologi reproduksi kerang pokea yaitu nisbah kelamin, fekunditas, tingkat kematangan gonad dan ukuran $50 \%$ matang gonad.

\section{DAFTAR PUSTAKA}

Amin SMN, Zafar M, Barua, M. 2009. Population Dynamics of Venus Clam Meretrix meretrix From the Moheshkali Island in the Cox's Bazar Coast of Bangladesh. Asian Fisheries Science. 22: 1031-1043.

Anthony JL, Kesler DH, Downing WL, Downing JA. 2001. Length-Specific Growth Rates in Freshwater Mussels (Bivalvia: Unionidae): Extreme Longevity or Generalized Growth Cessation?. J. Freshwater Biology. 46: 1349-1359.

Bahtiar, Yulianda F, Setyobudiandi I. 2008. Kajian Aspek Pertumbuhan Populasi Pokea (Batissa violacea var. celebensis, von Martens 1897) di Sungai Pohara Kendari Sulawesi Tenggara. Jurnal IImuIImu Perairan dan Perikanan Indonesia. 15(1): 1-5. 
Bahtiar, Riani E, Setyobudiandi I, Muchsin I. 2012a. Pengaruh Aktivitas Penambangan Pasir Terhadap Kepadatan dan Distribusi Pokea (Batissa violacea var. celebensis, von Martens 1897) di Sungai Pohara Kendari Sulawesi Tenggara. Agriplus. 22(1): 58-64.

Bahtiar, Riani E, Setyobudiandi I, Muchsin I. 2012b. Kepadatan dan Distribusi Pokea Batissa violacea var. celebensis, von Martens 1897) pada Substrat Berbeda di Sungai Pohara Kendari Sulawesi Tenggara. Aqua Hayati. 8(2): 115-123.

Bahtiar. 2012. Studi Bioekologi dan Dinamika Populasi Pokea (Batissa violacea var. celebensis von Martens, 1897) yang Tereksploitasi sebagai Dasar Pengelolaan di Sungai Pohara Sulawesi Tenggara. [Disertasi]. Bogor. Institut Pertanian Bogor.

Bahtiar, Nurgaya W, Anadi L. 2014. Studi Morfometrik dan Meristik Kerang Pokea (Batissa violacea var. celebensis von Martens, 1897) yang Tereksploitasi di Sungai Pohara Sulawesi Tenggara. Jurnal Biologi Tropis. 14(1) : 36-44.

Bahtiar, Nurgaya W, Irawati N. 2014. Studi Kebiasaan Makanan Kerang Pokea (Batissa violacea var. celebensis von Martens, 1897) Saat Penambangan Pasir di Sungai Pohara Sulawesi Tenggara. Jurnal Biologi Tropis. 14(2): 75-82.

Bahtiar, Hamzah M, Hari H. 2015. Studi Struktur dan Pertumbuhan Populasi Kerang Pokea (Batissa violacea var. celebensis, von Martens 1897) di Sungai Pohara Sulawesi Tenggara. Jurnal Biologi Tropis. 15(2): 110-120.

Boateng DA, Wilson JG. 2012. Population Dynamics of the Freshwater Clam Galatea Paradoxa from the Volta River, Ghana. Knowl. Managt. Aquatic Ecosyst. 405.

Bretos M. 1980. Age Determination in the Keyhole Limpet Fissurella crassa Lamarck (Archaeogastropoda: Fissurellidae), Based on Shell Growth Rings. Biological Bulletin. 159: 606-612.

Corte GN, Leonardo, Yokoyama LQ, Coleman RA, Amaral ACZ. 2015. Population Dynamics of the Harvested Clam Anomalocardia Brasiliana (Bivalvia: Veneridae) in Cidade Beach, South-East Brazil. Journal of the Marine Biological Association of the United Kingdom. 1-9 doi:10.1017 /S0025315415000156.
Djajasasmita M. 1977. An Anotated List of the Spesies of the Genus Corbicula from Indonesia (Mollusca: Corbiculidae). Amsterdam: Bulletin Zoologisch Museum, Universiteit Van Amsterdam. .

Dolorosa RG, Galon FD. 2014. Population Dynamics of the Mangrove Clam Polymesoda erosa (Bivalvia: Corbiculidae) in Iwahig, Palawan, Philippines. International Journal of Fauna and Biological Studies (IJFBS). 1(6): 11-15.

Dudgeon D, Morton B. 1989. The Population Dynamics and Sexual Strategy of Anodonta woodiana (Bivalvia: Unionidae) in Plover Cove Reservoir, Hongkong. J. Zool., Lond. 201: 161-183.

Efriyeldi, Bengen DG, Affandi R, T Prartono. 2012. Karakteristik Biologi Reproduksi Kerang Sepetang (Pharella acutidens) di Ekosistem Mangrove Dumai, Riau. Jurnal Perikanan Terubuk. 40(1): 36-44.

Gayanilo, Pauly D. 2002. The FAO-ICLARM. Stock Assessment Tools. (Fi-SAT Version 2001). http:/www.FAO.org/fi/ projects/fias. asp.

Gulland JA. 1977. Fish Population Dynamics. The Implications of Management. A Willey-Inter Science Publication. $2^{\text {nd }}$ ed. London: John Willey and Sons Ltd.

Heilmayer O, Brey T, Storch D, Mackensen A, Arntz WE. 2004. Population Dynamics and Metabolism of Aequipecten Opercularis (L.) from the Western English Channel (Roscoff, France). J Sea Res. 52: 3344

Hughes RN, Roberts DJ. 1980. Growth and Reproductive Rates of Littorina neritoides (L.) in North Wales. Journal of the Marine Biological Association of the United Kingdom. 60: 591-599.

Kusnoto. 1953. Kebun Raya Indonesia (Botanic Gardens of Indonesia). A Journal of Zoology, Hydrobiology and Oceanography of the Indo-Australian Archipelago. Jurnal Treubia. 22: 53-57.

Laxmilatha P. 2013. Population Dynamics of the Edible Clam Meretrix Casta (Chemnitz) (International Union For Conservation of Nature Status: Vulnerable) From Two Estuaries of North Kerala, South West Coast of India. International Journal of Fisheries and Aquaculture. 5(10):253-261.

Lomovasky BJ, Brey T, Morriconi E, Calvo J. 2002. Growth and Production of the 
Venerid Bivalve Eurhomalea exalbida in the Beagle Channel, Tierra del Fuego. $J$ Sea Res. 48: 209-216.

Metaxatos A. 2004. Population Dynamics of the Venerid Bivalve Callista chione (L.) in a Coastal Area of the Eastern Mediterranean. J Sea Res. 52: 293-305.

Muzuni, Adi DA, Syarif S. 2014. Karakterisasi Fragmen Gen 18s Rrna Pokea (Batissa violacea celebensis von Martens, 1897) di Sungai Pohara Kecamatan Sampara Kabupaten Konawe. Jurnal Biowallacea. 1(1): 25-38.

Narasimham, KA. 1981. Dimensional Relationships and Growth of Green Mussel Perna viridis in Kakinada Bay. Indian Journal of Fisheries. 28: 240-248.

Natan, Y. 2009. Parameter Populasi Kerang Lumpur Tropis Anodontia edentula di Ekosistem Mangrove. Jurnal Biologi Indonesia. 6(1): 25-38.

Ocaña, FA, Apín YC, Cala YR. 2013. Population Dynamic of Donax denticulatus (Bivalvia: Donacidae) at Carenero Beach, Southeastern Cuba. Rev Biol Trop. 61(4): 37-46.

Putri RE. 2005. Analisis Populasi dan Habitat: Sebaran Ukuran dan Kematangan Gonad Kerang Lokan Batissa violacea Lamarck (1818) di Muara Sungai Batang Anai Padang Sumatera Barat. [Tesis]. Bogor. Institut Pertanian Bogor.

Riascos JM, Heilmayer O, Laudien J. 2007. Population Dynamics of the Tropical
Bivalve Cardita Affinis From Malaga Bay, Colombian Pacific Related to La Nina 1999-2000. Helgol Mar Res. DOI 10.1007 /S10152-007-0083-6

Rueda M, Urban HJ. 1998. Population Dynamics and Fishery of the Freshwater Clam Polymesoda solida (Corbiculidae) in Cienaga Poza Verde, Salamanca Island, Colombian Caribbean. Fisheries Research. 39: 75-86.

Sastrapradja. 1977. Sumber Protein Hewani. Bogor: Lembaga Biologi Nasional-LIPI.

Schweers T, Wolff M, Koch V, Duarte FS. 2006. Population Dynamics of Megapitaria squalida (Bivalvia: Veneridae) at Magdalena Bay, Baja California Sur, Mexico. Rev. Biol. Trop (Int. J). 54(3): 1003-1017.

Sparre P, Venema SC. 1999. Introduksi Pengkajian Stok Ikan Tropis. Buku Manual (Edisi Terjemahan). Jakarta. Kerjasama Organisasi Pangan, Perserikatan Bangsa-Bangsa dengan Pusat Penelitian dan Pengembangan Perikanan, Badan Penelitian dan Pengembangan Pertanian.

Urban HJ, Campos B. 1994. Population Dynamics of the Bivalves Gari solida, Semele solida and Protothaca thaca From a Small Bay in Chile at 36"S. Marine Ecology Progress Series. 115: 93-102.

Zeinalipour M, Kiabi B, Shokri MR, Ardalan AA. 2014. Population Dynamic and Distribution of Barbatia decussata (Bivalvia: Arcidae) on Rocky Intertidal Shores in the Northern Persian Gulf (Iran). Tropical Zoology 27(3): 73-87. 